\title{
Preface to the second edition
}

I usually have a three-word description [of public choice] - it is 'politics without romance'. Politics is a romantic search for the good and the true and the beautiful. 'Public choice' came along and said, 'Why don't we model people more or less like everyday persons? Politicians and bureaucrats are no different from the rest of us. They will maximize their incentives just like everybody else.' By taking that very simple starting point, you get a completely different view of politics and its analysis.

(James M. Buchanan on how to define 'public choice') ${ }^{1}$

When we were approached to commission contributions for a new edition of The Elgar Companion to Public Choice some two years ago, we envisioned it not to be simply a follow-up or extension to the original volume. In essence, we wanted it to serve as a complement, which would stand on its own and highlight additional facets of this field that lies at the intersection of the economic and political sciences.

Although the approach we took to topic selection and the solicitation of potential contributors was broad, the chapters in this volume continue to emphasize the application of public choice theory to the study of collective decision-making on Election Day, in committees, in legislatures and in many other non-market settings, where choices are made in the absence of explicit price and profit signals and where the agreement of a qualified majority is required before action can be taken. The readers of this new Companion will encounter a wealth of evidence concerning the ability of public choice models to explain and predict the behavior of Homo economicus in all walks of life and in many marketplaces, be they for public goods and services, votes, religions, revolutions or judicial rulings, to name just a few. To that end, we have included chapters on topics not covered in the first edition, such as antitrust law enforcement, tribal systems of governance, instrumental versus expressive motives for voting, the political economy of war and peace, and transnational terrorism. We have also broadened our coverage geographically by adding relatively more contributions from scholars based in Europe.

The editors of the first edition of the Companion have been heartened by the positive response it received when it was published more than a decade ago; we are hopeful that this second edition, too, will establish itself as a valuable reference tool and compendium of new ideas for students and scholars of public choice alike. In working with the authors of the various chapters included in this volume, we have been impressed, once more, by the vibrant nature and the continuing applicability and viability of the by now wellestablished public choice research program.

We are grateful to the outstanding and helpful support we received from the staff at Edward Elgar. As with the first edition, the publisher provided us with the necessary support to bring this undertaking to fruition while giving us a completely free hand regarding the content and direction of the various parts of the project. Thankfully, Edward Elgar was very understanding when unforeseen circumstances caused a delay or two regarding the delivery of certain chapters. We would also like to thank Joshua Blotter for his eagle-eyed error-checking of the reference section. 
We are particularly indebted to the outstanding scholars who agreed to contribute to the first and the second editions of the Companion, most especially Randall Holcombe, who once again graciously came to the rescue when the promise made by another contributor fell through at the last minute. Given their prominence in the profession and the many time-intensive projects they are working on, we are aware of the high opportunity cost of their time. We, therefore, are even more appreciative of their commitment to this project.

Michael Reksulak

Laura Razzolini

William F. Shughart II

\section{NOTE}

1. 'Interview with James Buchanan, 1986 Nobel Prize Winner in Economics', available at: http://www.aims. ca/en/home/library/details.aspx/359 (accessed 20 January 2012). 